Fayoum Journal of Agricultural Research
and Development
ISSN:1110- 7790

\title{
Integrative effect of potassium level and deficit irrigation on physiological response, yield and water use efficiency of faba bean under salt affected soil
}

\author{
Fawzy S. Abdel Samie*1, Ayman H. Ali ${ }^{2}$, Mohamed O. A. Rady ${ }^{1}$, Shimaa A. Abd El \\ -Mageed ${ }^{1}$ \\ ${ }^{1}$ Agronomy Department, Faculty of Agriculture, Fayoum University, Fayoum, Egypt \\ ${ }^{2}$ Agronomy Department, Faculty of Agriculture, Beni-Suef University, Fayoum, Egypt.
}

\begin{abstract}
Two field experiments were conducted in 2018/19 and 2019/20 in salty soil ( ECe $6.86 \mathrm{dS} \mathrm{m}^{-1}$ ), on Vicia faba grown under three irrigation regimes $100 \%, 80 \%$ and $60 \%$ of crop evapotranspiration (ETc) combined with three potassium (K) levels (90, 120 and 150 $\left.\mathrm{kg} \mathrm{ha}^{-1}\right)$. The objective was to investigate the effects of potassium fertilizer application on faba bean morpho-physiological response under water stress. Plant water status (relative water content RWC, membrane stability index MSI), chlorophyll fluorescence $\left(F_{v} / F_{0}\right.$ and $P I)$ and SPAD index had been significantly affected by irrigation or/and potassium application. Potassium improved growth characteristics (i.e., plant height, number of branches per plant, number of leaves per plant, dry matter per plant and leaves area per plant) as well as nutrients contents of (N, P, K, and $\mathrm{Ca}$ ) and decrease of Na concentration in leaves. Seed yield and water use efficiency (WUE) were significantly affected by irrigation and potassium treatments. Results indicated that potassium application of $150 \mathrm{~kg}$ $\mathrm{ha}^{-1}$ and $120 \mathrm{~kg} \mathrm{ha}^{-1}$ significantly increased seed yield by $33.4 \%$ and $18.1 \%$, respectively, compared to $\left(90 \mathrm{~kg} \mathrm{ha}^{-1}\right)$ as average for two seasons. It was concluded that application of higher levels of potassium fertilizer in salt affected soil improves plant water status as well as growth and yield of faba bean under water scarcity.
\end{abstract}

\section{KEYWORDS}

abiotic stress, drought, nutrition status, chlorophyll fluorescence, yield and water use efficiency.

* Corresponding outhor: sa1944@ fayoum.edu.eg.

Received: 3/8/2021

Accepted: 26/8/ 2021 


\section{INTRODUCTION}

In arid and semi-arid countries water shortage is extremely affecting agricultural production. Therefore, there is increasing attention to improve water use efficiency in agriculture. In Mediterranean area where irrigation water is essential for production of crops, farmers are searching for new tools to save water by enhancing the efficiency of water use. Over worldwide, faba bean is characterized as one of the most significant legumes crops due to it's important for soil richness, human diet as a good source of vegetarian protein, animal feeding and industry purposes and it also, plays a vigorous role in the food chain. Moreover, it has become the most strategic crop due to its high income for the growers (Cazzato et al., 2012). Seeds of faba bean are rich in carbohydrates (51-68\%) Nachi and Guen, (1996) and proteins (28-30\%) of dry matter, Burbano et al. (1995). In Egypt, increasing quantity and quality of faba bean is the main goal to meet the request of the increasing Egyptian population since faba bean are a main part of the diet of Egyptian people (Zeidan, 2003). Water shortage turned into to a critical phenomenon worldwide, particularly in arid and semiarid area where water is required for growing of crops (Wei et al., 2016). In Mediterranean African countries, like Egypt, agriculture sector consumes nearly $80 \%$ of total water withdrawal. Hence, it is required to develop policies to improve water use efficiency, with keeping the quality and quantity of crop production (Pereira et al., 2012). In the last decade, the challenge is how to produce more yields from the restricted water resource. Egypt nowadays faces various challenges, such as; water scarcity initiated by human activities and environment variation, drought and desertification. Therefore, emerging technical performs and using the advanced irrigation-saving knowledge must be resented for improving faba bean productivity. Deficit irrigation (DI) was initiated in agriculture to increase the efficiency of irrigation water (Badal $\boldsymbol{e t}$ al., 2013). Numerous researchers documented that, the DI technique applied usually in water shortage conditions. (Agami et al., 2018 and Badal et al., 2013).

Successful management of the limited amount of water available for agricultural uses depends on better agricultural practices and enhanced understandings of water productivity (Howell 2001 and Jones 2004). Mineral-nutrient status of plants has a major role in its adaptation to stress. Potassium is one of the major nutrients considered essential for crop growth and yield development, although it is not an integral component of any cellular organelle or structural part of the plant. It is the most abundant cation in plants and is associated or involved with many of the physiological processes supporting plant growth and development (Abd El Mageed et al., 2017). Water relations, photosynthesis, assimilate transport and enzyme activation can be impacted by potassium. In this concern Mengel and Kirkby (2001) and Abid et al. (2016) found that, $\mathrm{K}$ regularizes physiological processes like photosynthesis, translocation of cations into sink organs, regulation of turgor pressure and enzymes activation. Cakmak (2005) indicated that plant suffering from water stress required more internal K. In legumes damaging effects of drought can be avoided by ample K supply (Sangakkara et al. 2000). Deficit irrigation combined with potassium fertilizer could be a very promising practice among the water management practices for increasing water use efficiency (WUE) especially at 
field scale. Low grain yield resulting from water deficit could be overcome by increasing K supply (Damon and Rengel 2007). Results reviewed in this section reveal that under water limited conditions, yield losses can be minimized by the sufficient supply of $K$. Owing to considerable evidence of the adverse effects of water stress on plant growth, it was hypothesized that the potassium fertilizer used in this study as a soil application can overcome the injurious effects of water stress on faba bean plants. Therefore, the present investigation was planned to determine the effects of potassium applications and irrigation levels plant growth, faba bean yields, and wateruse efficiencies under salt affected soil

\section{MATERIALS AND METHODS}

\subsection{Experimental location}

Two field experiments were conducted at a private farm located at El Fayoum region (latitudes $29^{\circ} 02^{\prime}$ and $29^{\circ} 35^{\prime} \mathrm{N}$ and longitudes $30^{\circ} 23^{\prime}$ and $31^{\circ} 05^{\prime} \mathrm{E}$ ), Egypt. According to Ponce et al. (2000) the soil is classified as arid climatic conditions. Table 1 shows soil properties (physical and chemical) of the experimental location which were analyzed according to the methods of Klute and Dirksen (1986) and Page et al. (1982).

Table 1. Some initial physico- chemical characteristics of the studied soils

\begin{tabular}{|c|c|c|c|c|c|c|c|c|c|c|c|}
\hline \multirow{2}{*}{ Season } & \multicolumn{3}{|c|}{$\begin{array}{c}\text { Particle size distribution, } \\
\%\end{array}$} & \multirow{2}{*}{$\begin{array}{l}\text { Texture } \\
\text { class }\end{array}$} & \multirow{2}{*}{$\begin{array}{c}\text { FC } \\
\%\end{array}$} & \multirow{2}{*}{$\begin{array}{l}\text { WP } \\
\%\end{array}$} & \multirow{2}{*}{$\underset{\%}{\mathrm{AW}}$} & \multirow{2}{*}{$\begin{array}{c}\text { ECe } \\
(\mathrm{dS} / \mathrm{m})\end{array}$} & \multirow{2}{*}{ pH } & \multirow{2}{*}{$\underset{\%}{\mathrm{O} M}$} & \multirow{2}{*}{$\begin{array}{c}\mathrm{CaCO}_{3} \\
\%\end{array}$} \\
\hline & Sand & Silt & Clay & & & & & & & & \\
\hline 2018/19 & 77.15 & 11.20 & 11.65 & LS & 25.15 & 10.72 & 14.43 & 7.13 & 7.45 & 1.08 & 4.28 \\
\hline $2019 / 20$ & 75.33 & 13.10 & 14.57 & LS & 24.19 & 11.22 & 12.97 & 6.52 & 7.76 & 0.95 & 4.66 \\
\hline
\end{tabular}

LS: loamy sand, ECe: the electrical conductivity, OM: organic matter content\%, FC: field capacity, WP: wilting point and AW: available water

Treatments were involved three levels of irrigation (I) and three potassium fertilizer treatments. I levels was specified as a percentage of the crop evapotranspiration (ETc) representing one of the following three treatments: $\mathrm{I}_{100}=100 \%, \mathrm{I}_{80}=80 \%$ and $\mathrm{I}_{60}=60 \%$ of ETc. I treatments were applied in the main plots, while the potassium fertilizer treatments namely $\left(\mathrm{K}_{1}\right.$ $=90 \mathrm{~kg} \mathrm{ha}^{-1}$, used as control, $\mathrm{K}_{2}=120 \mathrm{~kg}$ $\mathrm{ha}^{-1}$, and $\mathrm{K}_{3}=150 \mathrm{~kg} \mathrm{ha}^{-1}$, of the $\mathrm{K}_{2} \mathrm{O}$ ) were allocated in the sub-plots. The experiments were conducted in a randomized complete block design (Split Plot) in three replicates. Total of 9 treatments were replicated three times and the total experimental plots were 27. The experimental plot area was $18 \mathrm{~m}$ (length) $0.8 \mathrm{~m}$ (row width) $\left(14.4 \mathrm{~m}^{2}\right)$, each plot involved 3 planting rows and the space between plants within rows was $15 \mathrm{~cm}$.

\subsection{Agronomic management}

Healthy seeds of faba bean (Vicia faba. L, cultivar Sakha 1) were sown on 8 and 10 October of 2018/19 and 2019/20 and harvested on 15 and 20 April of 2018/2019 and 2019/2020, respectively. The used system of irrigation was drip irrigation and 2 drip-lines placed $50 \mathrm{~cm}$ apart in ever elementary test plot. The treatments of irrigation were started after full germination. Calcium superphosphate 
$\left(15.5 \% \mathrm{P}_{2} \mathrm{O}_{5}\right)$, as a source of phosphorus (370 $\mathrm{kg} \mathrm{ha}^{-1}$ ) was added to soil through the preparation of seedbed.

$150 \mathrm{~kg} \mathrm{ha}^{-1}$ in the form of ammonium nitrate $(33.5 \% \mathrm{~N})$ was added in 2 doses through the growing seasons (20 and 40 days after sowing) as a source of nitrogen. According to recommendations of the Ministry of Agriculture, Egypt, all cultural practices were done

\subsection{Irrigation water applied (IWA).}

The amounts of water were determined according to Allen et al. (1998) by using the next equation:

$$
\text { IWA }=\frac{A \times E T c \times I i}{E a \times(1-L R)}
$$

Where IWA, A, ETc, Ii, Ea and LR are the irrigation water applied $\left(\mathrm{m}^{3}\right)$, plot area $\left(\mathrm{m}^{2}\right)$, evapotranspiration $\left(\mathrm{mm} \mathrm{d}^{-1}\right)$, irrigation interval (day), application efficiency $(\%)$ and leaching requirements, respectively. ETc was estimated using the crop coefficient according to Allen et al. (1998) equation as fallow:

$$
\mathrm{ETc}=\mathrm{Kpan} \times \text { Epan } \times \mathrm{Kc}
$$

Where Kpan, Epan and Kc are the pan evaporation coefficient, evaporation from the Class A pan $\left(\mathrm{mm} \mathrm{d}^{-1}\right)$, and crop coefficient, respectively. Table 2 show the climatic data during growth seasons.

Table 2. Average monthly of weather data during the full course of investigation at

\begin{tabular}{|c|c|c|c|c|c|c|c|c|c|c|c|c|}
\hline \multirow{3}{*}{ Months } & \multicolumn{6}{|c|}{ 2018/19 } & \multicolumn{6}{|c|}{$2019 / 20$} \\
\hline & $\begin{array}{r}\text { Temp } \\
\text { re }\end{array}$ & $\begin{array}{l}\text { eratu } \\
\text { es }\end{array}$ & \multirow{2}{*}{$\begin{array}{l}\mathrm{RH} \\
(\%)\end{array}$} & \multirow{2}{*}{$\begin{array}{c}\mathbf{U}_{2} \\
\left(\mathrm{~m} \mathrm{~s}^{-1}\right)\end{array}$} & \multirow{2}{*}{$\begin{array}{c}\mathbf{E}_{\mathbf{p}} \\
(\mathbf{m m} \\
\left.\mathbf{d}^{-1}\right)\end{array}$} & \multirow{2}{*}{$\begin{array}{c}\text { Precipitatio } \\
\text { n } \\
(\mathbf{m m} \\
\left.\text { month }^{-1}\right)\end{array}$} & \multicolumn{2}{|c|}{$\begin{array}{l}\text { Temperatu } \\
\text { res }\left({ }^{\circ} \mathrm{C}\right) \\
\end{array}$} & \multirow{2}{*}{$\begin{array}{l}\text { RH } \\
(\%)\end{array}$} & \multirow{2}{*}{$\begin{array}{c}\mathbf{U}_{2} \\
\left(\mathrm{~m} \mathrm{~s}^{-1}\right)\end{array}$} & \multirow{2}{*}{$\begin{array}{c}\mathbf{E}_{\mathbf{p}} \\
(\mathbf{m m} \\
\left.\mathbf{d}^{-1}\right)\end{array}$} & \multirow{2}{*}{$\begin{array}{c}\text { Precipitatio } \\
\text { n }(\mathbf{m m} \\
\left.\text { month }^{-1}\right)\end{array}$} \\
\hline & Day & Night & & & & & Day & Night & & & & \\
\hline November & 28.11 & 14.48 & 42.0 & 1.90 & 2.10 & 5.4 & 28.10 & 15.60 & 42.0 & 1.60 & 2.20 & 7.5 \\
\hline December & 20.60 & 8.70 & 42.0 & 1.70 & 1.5 & 7.4 & 21.00 & 9.50 & 43.0 & 1.70 & 1.60 & 10.9 \\
\hline January & 17.97 & 6.01 & 42.6 & 2.20 & 1.60 & 8.4 & 20.50 & 8.50 & 43.6 & 1.90 & 1.90 & 11.5 \\
\hline February & 20.32 & 7.34 & 42.0 & 1.90 & 2.80 & 2.8 & 22.00 & 8.50 & 42.0 & 1.80 & 2.90 & 8.4 \\
\hline March & 24.68 & 9.59 & 36.6 & 2.20 & 3.90 & 62 & 27.30 & 12.60 & 37.6 & 2.00 & 3.90 & 93 \\
\hline
\end{tabular}
El-Fayoum region, Egypt.

$\mathrm{RH}=$ Relative humidity, $\mathrm{U}_{2}=$ Average of wind speed, and $\mathrm{E}_{\mathrm{P}}=$ Evaporation from standard Class-A pan.

2.4. Growth, physiological and water status measurements

At 90 days after sowing (DAS), samples of faba bean plants $(n=9)$ were collected from plots to determine number of leaves plant ${ }^{-1}$, plant height, number of branches plant ${ }^{-1}$, leaves area and dry weight plant $^{-1}$. Chlorophyll fluorescence ( $F v / F m$ and PI), as a convenient tool to assess photosynthetic efficiency, was determined according to Maxwell and Johnson, (2000) and Clark et al. (2000) by Handy PEA, Hansatech Instruments (Ltd, Kings Lynn, UK). Membrane stability index (MSI $\%$ ) and relative water content (RWC \%) were determined according to Rady, 
(2011) and Hayat et al. (2007), respectively. SPAD chlorophyll meter (SPAD-502; Minolta, Osaka, Japan) was used to determine relative contents of chlorophyll

\subsection{Nutrients Estimation}

Faba bean leaves nutrient contents $(\mathrm{N}, \mathrm{P}$, $\mathrm{K}, \mathrm{Ca}$ and $\mathrm{Na}$ ) were measured after ovendried and wet digestion with $\mathrm{HNO}_{3}$ and $\mathrm{H}_{2} \mathrm{O}_{2}$, samples were analyzed for $\mathrm{P}$ spectrophotometrically (Jackson 1973) and for $\mathrm{K}^{+}, \mathrm{Ca}^{2+}$ and $\mathrm{Na}^{+}$contents by Flame photometry (Gallenkamp Co., London,
U.K.). The $\mathrm{N}$ content was estimated by Kjeldahl digestion (Ningbo Medical Instruments Co., Ningbo, China).

\subsection{Yield, water productivity and water} use efficiency

At harvesting stage, randomly ten guarded plants were taken from every plot to determine yield components i.e., number of pods plant ${ }^{-1}$, pods weight plant ${ }^{-1}$ and 100- seed weight. Seeds of all plants per plot were utilized to determine seed yield $(\mathrm{t}$ $\left.\mathrm{ha}^{-1}\right)$.

Water use efficiency (WUE) was calculated using the equation of (Jensen 1983)

$$
\text { WUE }=\frac{\text { seed yield }\left(\mathrm{Kg} \mathrm{fed}^{-1}\right)}{\text { water applied }\left(\mathrm{m}^{3} \mathrm{fed}^{-1}\right)}
$$

\subsection{Statistical analysis.}

The results were statistically analyzed according to Gomez and Gomez (1984) using ANOVA procedures in GenStat statistical package (version 11) (VSN International Ltd, Oxford, UK).

\section{RESULTS AND DISCUSSION}

\section{1. Effect of potassium fertilizer and deficit irrigation on water status of faba bean plants}

\subsubsection{Relative water content (RWC) and membrane stability index (MSI)}

Responses of RWC and MSI of faba bean plants to potassium fertilizer and deficit irrigation (DI) are presented in Fig 1. Statistical analysis carried out on RWC and MSI showed a significant difference (P $\leq 0.05$ ) between DI and potassium fertilizers treatments. RWC and MSI was decreased with increasing DI. Addition of potassium found to modify the DI-affected RWC and MSI. The greatest results for these attributes were recorded under $\mathrm{K}_{3}+$ $\mathrm{I}_{100}$ treatment. In this scene, Sinclair and
Ludlow (1986) revealed that RWC and MSI considers a measure of plant water status, reflecting the metabolic activity in plant tissues and used as a most meaningful index to identify the legumes with contrasting differences in dehydration tolerance. Application higher amounts of potassium improved water relative content (Kabir et al., 2004). A relationship was observed between RWC\% and MSI\% and plant biomass dry weight) under the interactive effect of deficit irrigation, and potassium, indicating that the water status in faba bean leaves is basically dependent on the respective shoot biomass. This also suggests that, faba bean plants having greater biomass can maintain higher water content in leaf, leading to more tolerance to drought. Our results agree with (Kabir et al., (2004) and Abd El-Mageed et al., (2017) who also reported that the RWC vs. plant biomass or growth could be used as a convenient evidence to distinguish the specific and non-specific traits for drought tolerance in faba bean plants, similar to 
what has been reported for other crops in semi-arid environment and drip irrigation

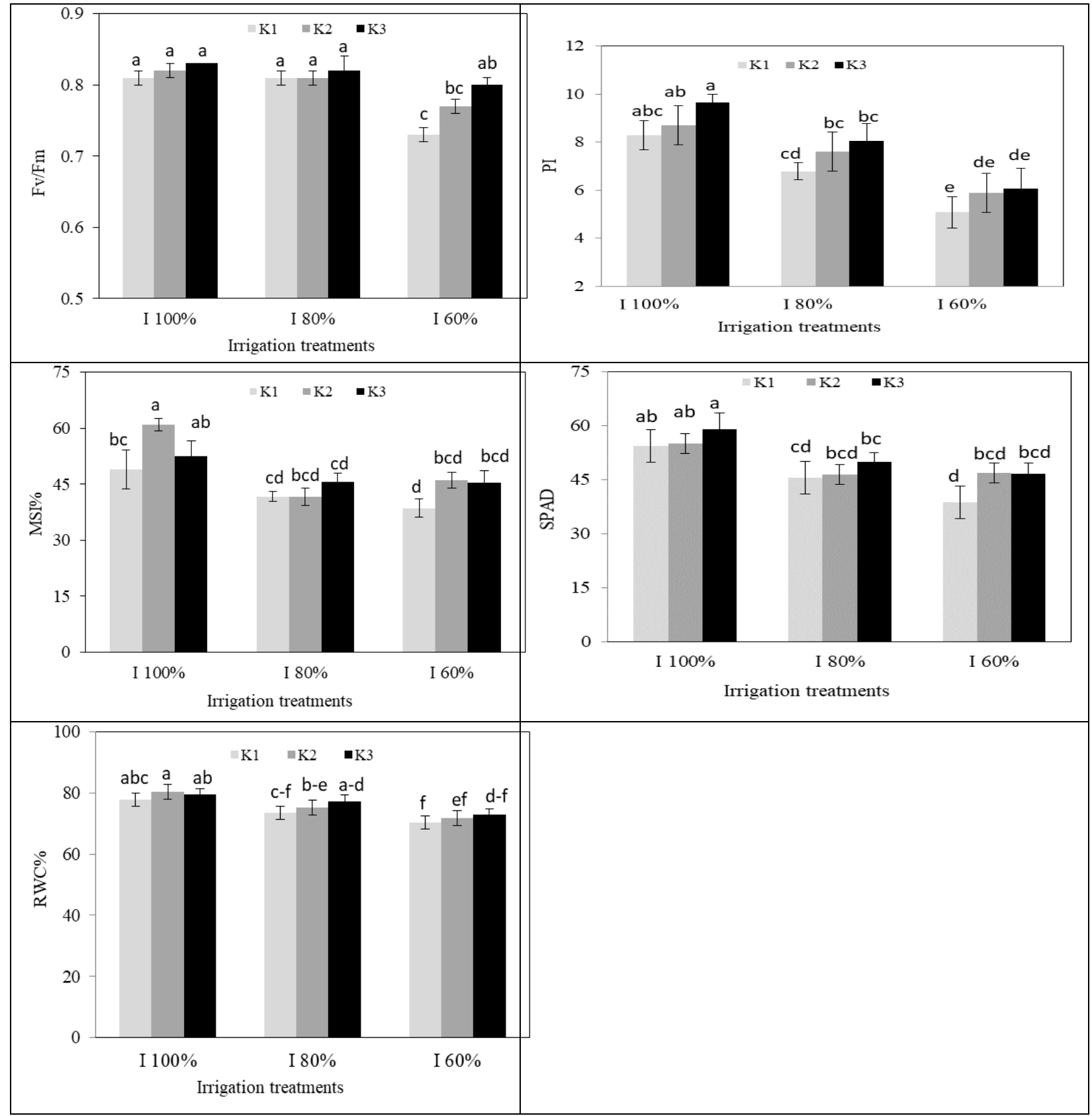

Figure 1. Leaf physiology parameter of faba bean plants grown under different irrigation levels $\left(\mathrm{I}_{100}\right.$, irrigation with $100 \%$; $\mathrm{I}_{85}$, irrigation with $85 \%$; and $\mathrm{I}_{70}$, irrigation with $70 \%$ of evapotranspiration) and potassium fertilizer treatments. Vertical bars represent means of 3 replications \pm S.E $(\mathrm{p} \leq 0.05)$. Columns marked by different letters are significantly different 


\subsubsection{Chlorophyll efficiency and chlorophyll content (SPAD)}

Figure 1 showed the combined effects of potassium and DI on $F v / F m$ and performance index (PI) in two growing seasons. These attributes were significantly or insignificantly reduced gradually with the gradual increase in DI for two seasons. However, applications of potassium have been shown to mitigate the adverse effects of DI on chlorophyll fluorescence and chlorophyll content (SPAD) in leaves of faba bean plants. The highest chlorophyll fluorescence and SPAD values were achieved when adequate water was applied $\left(\mathrm{I}_{100}\right.$ and $150 \mathrm{~kg} \mathrm{ha}^{-1}$ of $\left.\mathrm{K}_{2} \mathrm{O}\right)$. Whereas the lowest values of chlorophyll fluorescence and SPAD values were observed in more severe DI treatment, DI60\% and $90 \mathrm{~kg} \mathrm{ha}^{-1}$ of $\mathrm{K}_{2} \mathrm{O}$. Many reports suggested that using the analysis of chlorophyll fluorescence as a reliable method to determine the changes in the function of PSII under stress conditions (Cakmak 2005 and Abd ElMageed and Semida 2015). Lower photosynthetic activity could be a result in low photochemical efficiency of PSII, as revealed by its lower quantum yield (Pieters and Souki 2005). Our results showed reductions in $F_{v} / F_{m}$ and performance index (PI) (Figure 1) under DI stress conditions, which were possibly due to the reduction in leaf photosynthetic pigments and RWC needed for photosynthesis. These results are in parallel line with those of Abd El-Mageed and Semida (2015). Habibi (2012) concluded that decreasing $F_{\mathrm{v}} / F_{\mathrm{m}}$ values implies that photochemical conversion efficiency could indicate the possibility of photo-inhibition. The decrease in photosynthetic performance under water stress has also been observed by Ben Ahmed et al. (2009) and Habibi (2012). These reports concluded a significant correlation between $F_{\mathrm{v}} / F_{\mathrm{m}}$ and $g_{s}$ that confirmed the idea that stomatal closure that limits $\mathrm{CO}_{2}$ availability for dark reactions may be one of the mechanisms for photo-inhibition in DIstressed leaves (Damon and Rengel 2007). Water stress may also reduce photosynthesis rate through direct influence on the metabolic and photochemical processes in the leaf, or indirect influence on stomatal closure and cessation of leaf growth which results in decreased leaf surface area (Dejong, 1996).

\subsection{Plant growth attributes}

All growth attributes of faba bean (plant height, number of branches per plant, number of leaves per plant, dry matter per plant, and leaf area) were statistically analyzed as shown in (Table 3). Plant height, number of branches per plant, number of leaves per plant were not significantly affected by seasons but dry matter and leaves area were highly significant affected by seasons. 
Table 3. Effect of potassium fertilizer and deficit irrigation on plant height (cm), number of branches per plant, number of leaves per plant, dry matter per plant (g)and leaves area per plant $\left(\mathrm{dm}^{2}\right)$ of faba bean plants grown under salt affected soil in 2018/19 and 2019/20.

\begin{tabular}{cccccc}
\hline $\begin{array}{c}\text { Source of } \\
\text { variation }\end{array}$ & $\begin{array}{c}\text { Plant height, } \\
\mathbf{c m}\end{array}$ & $\begin{array}{c}\text { Number of } \\
\text { branches } \\
\text { per plant }\end{array}$ & $\begin{array}{c}\text { Number of } \\
\text { leaves per } \\
\text { plant }\end{array}$ & $\begin{array}{c}\text { Dry matter per } \\
\text { plant }(\mathbf{g})\end{array}$ & $\begin{array}{c}\text { Leaves area } \\
\text { per plant } \\
\left(\mathbf{d m}^{2}\right)\end{array}$ \\
\hline Seasons (S) & $\mathrm{NS}$ & $\mathrm{NS}$ & $\mathrm{NS}$ & $* *$ & $* *$ \\
$\mathrm{~S}_{\mathrm{I}}$ & $89.32 \pm 1.39 \mathrm{a}$ & $4.29 \pm 0.12 \mathrm{a}$ & $70.42 \pm 1.53 \mathrm{a}$ & $60.79 \pm 2.03 \mathrm{a}$ & $152.9 \pm 6.69 \mathrm{a}$ \\
$\mathrm{S}_{\mathrm{II}}$ & $87.62 \pm 1.23 \mathrm{a}$ & $4.11 \pm 0.09 \mathrm{a}$ & $68.63 \pm 1.41 \mathrm{a}$ & $58.96 \pm 1.63 \mathrm{~b}$ & $152.89 \pm 7.63 \mathrm{a}$ \\
Irrigation level (I) & $* *$ & $* *$ & $* *$ & $* *$ & $* *$ \\
$\mathrm{I}_{100 \%}$ & $93.47 \pm 0.83 \mathrm{a}$ & $4.56 \pm 0.11 \mathrm{a}$ & $76.2 \pm 1.49 \mathrm{a}$ & $63.64 \pm 1.63 \mathrm{a}$ & $184.7 \pm 6.67 \mathrm{a}$ \\
$\mathrm{I}_{80 \%}$ & $87.68 \pm 1.38 \mathrm{~b}$ & $4.07 \pm 0.18 \mathrm{~b}$ & $72.2 \pm 1.18 \mathrm{a}$ & $62.70 \pm 2.08 \mathrm{a}$ & $159.6 \pm 5.32 \mathrm{~b}$ \\
$\mathrm{I}_{60 \%}$ & $84.27 \pm 1.39 \mathrm{c}$ & $3.96 \pm 0.14 \mathrm{~b}$ & $60.2 \pm 1.50 \mathrm{~b}$ & $53.27 \pm 1.39 \mathrm{~b}$ & $114.4 \pm 4.03 \mathrm{c}$ \\
Potassium $(\mathrm{K})$ & $* *$ & $* *$ & $* *$ & $* *$ & $* *$ \\
$\mathrm{~K}_{1}$ & $84.30 \pm 1.43 \mathrm{c}$ & $3.82 \pm 0.15 \mathrm{~b}$ & $60.6 \pm 1.73 \mathrm{~b}$ & $53.85 \pm 1.48 \mathrm{~b}$ & $138 \pm 7.42 \mathrm{c}$ \\
$\mathrm{K}_{2}$ & $88.74 \pm 1.32 \mathrm{~b}$ & $4.22 \pm 0.14 \mathrm{a}$ & $72.8 \pm 1.19 \mathrm{a}$ & $61.66 \pm 1.71 \mathrm{a}$ & $152.8 \pm 7.42 \mathrm{~b}$ \\
$\mathrm{~K}_{3}$ & $92.37 \pm 1.07 \mathrm{a}$ & $4.56 \pm 0.12 \mathrm{a}$ & $75.2 \pm 1.43 \mathrm{a}$ & $64.10 \pm 2.03 \mathrm{a}$ & $167.9 \pm 7.72 \mathrm{a}$ \\
$\mathrm{S} \times \mathrm{I}$ & $\mathrm{NS}$ & $*$ & $*$ & $\mathrm{NS}$ & $\mathrm{NS}$ \\
$\mathrm{S} \times \mathrm{K}$ & $*$ & $\mathrm{NS}$ & $\mathrm{NS}$ & $*$ & $*$ \\
$\mathrm{I} \times \mathrm{K}$ & $* *$ & $* *$ & $* *$ & $* *$ & $* *$ \\
$\mathrm{~S} \times \mathrm{I} \times \mathrm{K}$ & $\mathrm{NS}$ & $*$ & $\mathrm{NS}$ & $\mathrm{NS}$ & $\mathrm{NS}$ \\
\hline
\end{tabular}

** and $*$ indicate respectively differences at $\mathrm{P} \leq 0.05$ and $\mathrm{P} \leq 0.01$ probability level, ns indicates not significant difference. Means followed by the same letter in each column are not significantly different according to the LSD test $(\mathrm{P}<0.05)$.

Plant height, number of branches per plant, number of leaves per plant, dry matter per plant, and leaf area were significantly affected by irrigation quantity and potassium application. Results in Table 3 showed that significant differences $(\mathrm{P}<$ $0.05)$ were observed for the interaction between I and potassium. Additionally, plant height, number of branches per plant, number of leaves per plant, dry matter per plant, and leaf area were also significantly $(\mathrm{P}<0.05)$ affected by the interaction between I, and potassium application. The highest values of plant height, number of branches per plant, number of leaves per plant, dry matter per plant, and leaf area had been recorded when faba bean plants were subjected to full irrigation $\left(\mathrm{I}_{100}\right)$ and received $150 \mathrm{~kg} \mathrm{ha}^{-1}$ of potassium fertilizer $\left(\mathrm{K}_{2} \mathrm{O}\right)$ for the two seasons. However, the lowest growth parameters was obtained under water-deficit conditions ( $\left.\mathrm{I}_{60}\right)$ combined with $90 \mathrm{~kg} \mathrm{ha}^{-1}$ of potassium. Potassium treatments had clear effect on growth parameters such as plant height, number of branches per plant, number of leaves per plant, dry matter per plant, and leaf area. Plant height, number of branches per plant, number of leaves per plant, dry matter per plant, and leaf area were significantly $(\mathrm{P}<0.05)$ decreased under stressed treatment. However, potassium fertilizer influence on growth traits was more important under deficit irrigation conditions. Results indicated that dry matter of plant was negatively affected by deficit irrigation, confirming those obtained by Gonzalez et al. (2009) who reported that dry weight of the whole plant as well as that of individual plants was higher in the control than under drought. This results also in agreement also with those obtained by Ofosu-Anim and Leitch (2009).

\subsection{Water use efficiency (WUE)}


Water use efficiency (WUE) was significantly affected by irrigation regime and potassium application $(\mathrm{P}=0.05$; Table 4). In fact, no differences effect between years on WUE was found. WUE increased with passing from fully irrigated plants (1.2 $\mathrm{kg} \mathrm{m}^{-3}$ ) to sever irrigation treatment $(1.53$ $\mathrm{kg} \mathrm{m}^{-3}$ ). Moreover, as a consequence of the higher yield recorded with potassium application (Table 4), (WUE) was higher by $6.9 \%$ and $11.45 \%$ in $K_{3}$ and $K_{3}$ in respect to $\mathrm{K}_{1}$ treatment

Table 4. Effect of potassium fertilizer and deficit irrigation on number of pods, pods weight per plant (g) weight of 100 seeds, yield and water use efficiency (WUE) of faba bean plants grown under salt affected soil in 2018/19 and 2019/20 years.

\begin{tabular}{cccccc}
\hline Source of variation & $\begin{array}{c}\text { No of pods per } \\
\text { plant }\end{array}$ & $\begin{array}{c}\text { Pods weight } \\
\text { per plant }(\mathbf{g})\end{array}$ & $\begin{array}{c}\text { Weight of 100 } \\
\text { seed }(\mathbf{g})\end{array}$ & $\begin{array}{c}\text { Yield } \\
\mathbf{t h a}^{-1}\end{array}$ & $\begin{array}{c}\text { WUE } \\
\left(\mathbf{K g ~ m}^{-3}\right)\end{array}$ \\
\hline Season (S) & $\mathrm{NS}$ & $* *$ & $\mathrm{NS}$ & $\mathrm{NS}$ & $\mathrm{NS}$ \\
$\mathrm{S}_{\mathrm{I}}$ & $15.38 \pm 0.43 \mathrm{a}$ & $69.36 \pm 1.16 \mathrm{a}$ & $80.83 \pm 1.23 \mathrm{a}$ & $4.42 \pm 0.08 \mathrm{a}$ & $1.42 \pm 0.03 \mathrm{a}$ \\
$\mathrm{S}_{\mathrm{II}}$ & $15.83 \pm 0.42 \mathrm{a}$ & $71.26 \pm 1.29 \mathrm{~b}$ & $82.91 \pm 1.12 \mathrm{a}$ & $4.16 \pm 0.09 \mathrm{a}$ & $1.36 \pm 0.03 \mathrm{a}$ \\
Irrigation level (I) & $* *$ & $* *$ & $* *$ & $* *$ & $* *$ \\
$\mathrm{I}_{100 \%}$ & $17.14 \pm 0.39 \mathrm{a}$ & $75.23 \pm 1.17 \mathrm{a}$ & $88.07 \pm 0.74 \mathrm{a}$ & $4.71 \pm 0.08 \mathrm{a}$ & $1.20 \pm 0.02 \mathrm{c}$ \\
$\mathrm{I}_{80 \%}$ & $15.94 \pm 0.39 \mathrm{~b}$ & $70.91 \pm 1.29 \mathrm{~b}$ & $83.01 \pm 1.37 \mathrm{a}$ & $4.55 \pm 0.07 \mathrm{a}$ & $1.45 \pm 0.02 \mathrm{~b}$ \\
$\mathrm{I}_{60 \%}$ & $13.65 \pm 0.39 \mathrm{c}$ & $64.78 \pm 1.36 \mathrm{c}$ & $74.53 \pm 1.41 \mathrm{~b}$ & $3.60 \pm 0.07 \mathrm{~b}$ & $1.53 \pm 0.03 \mathrm{a}$ \\
Potassium $(\mathrm{K})$ & $* *$ & $* *$ & $* *$ & $* *$ & $* *$ \\
$\mathrm{~K}_{1}$ & $13.65 \pm 0.34 \mathrm{c}$ & $65.75 \pm 1.14 \mathrm{c}$ & $72.47 \pm 1.50 \mathrm{c}$ & $3.66 \pm 0.11 \mathrm{c}$ & $1.31 \pm 0.04 \mathrm{~b}$ \\
$\mathrm{~K}_{2}$ & $15.79 \pm 0.44 \mathrm{~b}$ & $70.64 \pm 1.40 \mathrm{~b}$ & $83.08 \pm 0.87 \mathrm{~b}$ & $4.32 \pm 0.12 \mathrm{~b}$ & $1.40 \pm 0.04 \mathrm{a}$ \\
$\mathrm{K}_{3}$ & $17.28 \pm 0.44 \mathrm{a}$ & $74.53 \pm 1.49 \mathrm{a}$ & $90.07 \pm 0.73 \mathrm{a}$ & $4.88 \pm 0.12 \mathrm{a}$ & $1.46 \pm 0.04 \mathrm{a}$ \\
$\mathrm{S} \times \mathrm{I}$ & $\mathrm{NS}$ & $*$ & $\mathrm{NS}$ & $*$ & $\mathrm{NS}$ \\
$\mathrm{S} \times \mathrm{K}$ & $\mathrm{NS}$ & $*$ & $\mathrm{NS}$ & $*$ & $*$ \\
$\mathrm{I} \times \mathrm{K}$ & $* *$ & $* *$ & $* *$ & $* *$ & $* *$ \\
$\mathrm{~S} \times \mathrm{I} \times \mathrm{K}$ & $*$ & $\mathrm{NS}$ & $*$ & $\mathrm{NS}$ & $\mathrm{NS}$ \\
\hline
\end{tabular}

$* *$ and $*$ indicate respectively differences at $\mathrm{P} \leq 0.05$ and $\mathrm{P} \leq 0.01$ probability level, ns indicates not significant difference. Means followed by the same letter in each column are not significantly different according to the LSD test $(\mathrm{P}<0.05)$.

This result may be due to that, faba bean yield gained under 2018/19 (4.43 $\left.\mathrm{t} \mathrm{ha}^{-1}\right)$ was higher than the corresponding faba bean yield gained under 2019/20 (4.29 $\mathrm{t} \mathrm{ha}^{-}$ ${ }^{1}$ ) by $3 \%$. These results are in agreement with those of Rouphael and Colla (2005); Al-Mefleh et al. (2012) and Abd ElMageed et al. (2017) who mentioned that increasing irrigation levels did not increase the WUE in faba bean.

WUE increased with increasing water shortage in the root zone, indicating that yield losses was proportionally smaller than the amount of water used by crops. These findings are disagreement with results obtained by Nuruddin et al. (2003). Other authors observed higher WUE under moderate water stress and a decrease of WUE under severe water stress conditions (Wang et al. 2011 and Liu et al. 2013). However, other authors reported that WUE is positively affected by water deficit (Chen et al. 2013; Abd El-Mageed and Semida 2015). The different effects of water deficit on WUE observed in various studies can be attributed to the level of water stress experienced by the crop. Indeed, under mild water stress, when slight stomata closure occurs, transpiration decreases more than photosynthesis and, consequently, WUE increases. On the contrary, severe drought may lead to full closure of stomata and decrease of WUE and yield (Beukema and Van Der Zaag 
1990). Faba bean crop can develop deep root system in deep soils with more potassium addition, which potentially increases the water availability for the plants and attenuates negative effects of water deficit. This may bring up the crop more resistant to water stress and a greater WUE. In the shallow soils, as in our experiment, the development of the rooting system was very limited; it resulted in severe water stress with a very negative impact on the yield and WUE. The application of potassium improved WUE, as well as yield, in agreement with results reported by Giuliani et al. (2011).

\subsection{Yield and yield component}

Number of pods per plant, Pods weight per plant (g) Weight of 100 seed (g) seed Yield $\mathrm{t} \mathrm{ha}^{-1}$ were significantly affected by irrigation regime (Tables 5). Fully irrigated $(100 \%)$ plants gave higher no. of pods (17.14 plant $\left.^{-1}\right)$ and greater total seed yield (4.71 $\mathrm{t} \mathrm{ha}^{-1}$ ) than $\mathrm{I}_{80 \%}$ (15.94 plant $^{-1}$ and $\left.4.55 \mathrm{t} \mathrm{ha}^{-1}\right)$ and severe stress plants $\left(\mathrm{I}_{60 \%}\right)$ (13.65 plant $^{-1}$ and $3.60 \mathrm{t} \mathrm{ha}^{-1}$ ). In addition, fully irrigated plants showed higher weight of 100 seed $(88.07 \mathrm{~g})$ than $\mathrm{I}_{80 \%}(83.01 \mathrm{~g})$ and $\mathrm{I}_{60 \%}(74.53 \mathrm{~g})$. Potassium application $\left(\mathrm{K}_{3}\right)$ increased seed yield (by $33.3 \%$ and $13.0 \%$ ) in comparison to $\left(\mathrm{K}_{1}\right)$ and $\left(\mathrm{K}_{2}\right)$, respectively, (Table 5). Faba bean yield sharply decreased with the irrigation water reduction in both growing seasons, confirming that faba bean is one of the most water demanding crops (Danial et al., 2010). In fact, as average of the two years (2018/2019 and 2019/2020), yield dropped by $3.4 \%$ in $\mathrm{I}_{80 \%}$ and by $23.6 \%$ in $\mathrm{I}_{60 \%}$, in respect to full irrigated crop. Many studies showed that water deficit at certain levels decreased faba bean yield (Matusso et al. 2014), although at a different extent depending on the period and the degree of water stress (El Sayed and Ahmad 2003 and Ijoyah and Fanen 2012). The decline in weight of 100 seed $(5.7 \%$ and $15.4 \%$ for $\mathrm{I}_{80 \%}$ and $\mathrm{I}_{60 \%}$, respectively) was not the only parameter contributing to the reduction in yield, but also may be due to the reduction in the number of pods per plant $(5.7 \%$ and $13.9 \%$ for $\mathrm{I}_{80 \%}$ and $\mathrm{I}_{60 \%}$, respectively,) as observed in other studies (Abd El Mageed et al., 2021). The reduction of faba bean yield due to water shortage, in some cases is attributed only to the decline in the number of pods per plant (Matusso et al., 2014), but in other cases also to a reduction in the number of branches (EI Sayed and Ahmad 2003 and Ijoyah and Fanen 2012). These differences are attributable to the intensity and duration of water stress and to the phonological stage in which the stress occurs. Generally, a reduction of yield occurs under longer and more intense periods of stress, as recorded in our experiment. The application of potassium significantly improved yield. These results are consistent with previous findings obtained on faba bean utilizing potassium (Abd El Mageed et al., 2021). Our study showed that a positive interaction between irrigation regimes and application of potassium was shown for number of pods and WUE, further than a moderate improvement of plant water status in terms of both RWC and chlorophyll fluorescence.

\subsection{Nutrients status of the plants}

The concentrations of $\mathrm{N}, \mathrm{P}, \mathrm{K}, \mathrm{Ca}$ and $\mathrm{Na}$ are presented in Table 5. Statistically significant differences between the potassium levels were noted for $\mathrm{N}, \mathrm{P}, \mathrm{K}, \mathrm{Ca}$ and $\mathrm{Na}$ concentrations. Concerning the effect of irrigation treatments on nutrients uptake, results revealed that the highest $\mathrm{N}$, $\mathrm{P}, \mathrm{K}, \mathrm{Ca}$ concentrations were recorded under fully irrigated plants $\left(\mathrm{I}_{100 \%}\right)$. Also, results showed that the highest $\mathrm{N}, \mathrm{P}, \mathrm{K}, \mathrm{Ca}$ concentrations were noted in plants treated with $150 \mathrm{~kg} \mathrm{ha}^{-1}$. On the other hand, the lowest $\mathrm{Na}$ concentration was obtained from 
plants treated with $90 \mathrm{~kg} \mathrm{ha}^{-1}$. The higher concentrations of nutrients, increased rates of potassium to soil led to including elemental $\mathrm{K}$.

Table 5. Effect of potassium fertilizer and deficit irrigation on the contents of macronutrients (N, P, K, Ca and Na) of faba bean plants grown under salt affected soil in 2018/19 and 2019/20 seasons

\begin{tabular}{cccccc}
\hline Source of variation & $\mathbf{N}$ & $\mathbf{P}$ & $\mathbf{K}$ & $\mathbf{C a}$ & $\mathbf{N a}$ \\
\hline Season $(\mathrm{S})$ & $\mathrm{NS}$ & $*$ & $\mathrm{NS}$ & $\mathrm{NS}$ & $\mathrm{NS}$ \\
$\mathrm{S}_{\mathrm{I}}$ & $38.11 \pm 0.51 \mathrm{a}$ & $11.13 \pm 0.56 \mathrm{~b}$ & $18.83 \pm 0.36 \mathrm{a}$ & $20.05 \pm 0.69 \mathrm{a}$ & $19.42 \pm 0.45 \mathrm{a}$ \\
$\mathrm{S}_{\mathrm{II}}$ & $36.10 \pm 0.52 \mathrm{a}$ & $12.92 \pm 0.53 \mathrm{a}$ & $17.62 \pm 0.44 \mathrm{a}$ & $21.07 \pm 0.86 \mathrm{a}$ & $20.20 \pm 0.53 \mathrm{a}$ \\
Irrigation level (I) & $* *$ & $* *$ & $* *$ & $* *$ & $* *$ \\
$\mathrm{I}_{100 \%}$ & $41.21 \pm 0.54 \mathrm{a}$ & $13.87 \pm 0.45 \mathrm{a}$ & $19.37 \pm 0.54 \mathrm{a}$ & $22.63 \pm 0.69 \mathrm{a}$ & $18.63 \pm 0.41 \mathrm{~b}$ \\
$\mathrm{I}_{80 \%}$ & $35.85 \pm 0.53 \mathrm{~b}$ & $11.86 \pm 0.52 \mathrm{~b}$ & $18.05 \pm 0.53 \mathrm{ab}$ & $20.74 \pm 0.55 \mathrm{~b}$ & $18.82 \pm 0.53 \mathrm{~b}$ \\
$\mathrm{I}_{60 \%}$ & $34.26 \pm 0.57 \mathrm{~b}$ & $8.87 \pm 0.31 \mathrm{c}$ & $17.26 \pm 0.63 \mathrm{~b}$ & $18.30 \pm 0.77 \mathrm{c}$ & $21.98 \pm 0.46 \mathrm{a}$ \\
Potassium $(\mathrm{K})$ & $* *$ & $* *$ & $* *$ & $* *$ & $* *$ \\
$\mathrm{~K}_{1}$ & $33.26 \pm 0.49 \mathrm{c}$ & $10.58 \pm 0.58 \mathrm{~b}$ & $16.26 \pm 0.45 \mathrm{~b}$ & $18.00 \pm 0.77 \mathrm{c}$ & $21.47 \pm 0.51 \mathrm{a}$ \\
$\mathrm{K}_{2}$ & $36.85 \pm 0.49 \mathrm{~b}$ & $11.65 \pm 0.60 \mathrm{ab}$ & $18.70 \pm 0.50 \mathrm{a}$ & $20.67 \pm 0.62 \mathrm{~b}$ & $19.40 \pm 0.46 \mathrm{~b}$ \\
$\mathrm{~K}_{3}$ & $41.61 \pm 0.50 \mathrm{a}$ & $12.38 \pm 0.53 \mathrm{a}$ & $19.72 \pm 0.48 \mathrm{a}$ & $22.41 \pm 0.67 \mathrm{a}$ & $18.55 \pm 0.55 \mathrm{~b}$ \\
$\mathrm{~S} \times \mathrm{I}$ & $\mathrm{NS}$ & $\mathrm{NS}$ & $*$ & $*$ & $\mathrm{NS}$ \\
$\mathrm{S} \times \mathrm{K}$ & $\mathrm{NS}$ & $* *$ & $\mathrm{NS}$ & $\mathrm{NS}$ & $*$ \\
$\mathrm{I} \times \mathrm{K}$ & $* *$ & $* *$ & $* *$ & $*$ & $* *$ \\
$\mathrm{~S} \times \mathrm{I} \times \mathrm{K}$ & $\mathrm{NS}$ & $*$ & $*$ & $\mathrm{NS}$ & $\mathrm{NS}$ \\
\hline
\end{tabular}

$* *$ and $*$ indicate respectively differences at $\mathrm{P} \leq 0.05$ and $\mathrm{P} \leq 0.01$ probability level, ns indicates not significant difference. Means followed by the same letter in each column are not significantly different according to the LSD test $(\mathrm{P}<0.05)$.

Data in Table 5 show significantly increased of N, P, K and Ca in leaves of faba bean as a result of $\mathrm{K}$ supply increased up to 120 or $150 \mathrm{~kg} \mathrm{~K}_{2} \mathrm{O}$ ha ${ }^{-1}$ under irrigation treatments. In this concern, Abd El Mawly (1987) reported that, values of N, P and K uptake faba bean plants, as shown in Table 5, showed also gradually increases as a result of increasing $\mathrm{K}$ rates up to $150 \mathrm{~kg} \mathrm{~K}_{2} \mathrm{O}$ ha $^{-1}$.

\section{Conclusion}

Exposure of faba bean plants to DI resulted in decreases in plant growth, RWC, leaf photosynthetic pigments, yield and increased WUE. Overall, the present study revealed that the application of potassium fertilizer could overcome the adverse effects of DI stress by increasing RWC, SPAD acting as osmotic and metabolic regulators or substrates and in a part as cell indicated that potassium application at high level $\left(150 \mathrm{Kg} \mathrm{ha}^{-1}\right)$ is useful for improving the growth (i.e., plant height, number and area of leaves per plant and plant dry weight), contents of $\mathrm{N}, \mathrm{P}, \mathrm{K}, \mathrm{Ca}$ and $\mathrm{Na}$. WUE and yield of faba bean crop under DI by $18 \%-33 \%$. This gives additional insight to the application of potassium fertilizer with deficit irrigation in arid environments component stabilizers. These results 


\section{REFERENCES}

Abd El Mawly S.E. 1987. Effect of potassium and phosphate application on yield and chemical composition of faba bean. M.Sc. Thesis, Fac. of Agric., Minia University., Egypt.

Abd El-Mageed T.A., and Semida W.M. 2015. Organo mineral fertilizer can mitigate water stress for cucumber production (Cucumis sativus L.). Agric Water Manage.159: 1-10.

Abd El-Mageed, T.A., El-Sherif, A.M.A., Ali, M.M., and Abd El-Wahed, M.H. 2017. Combined effect of deficit irrigation and potassium fertilizer on physiological response, plant water status and yield of soybean in calcareous soil. Arch. Agron. Soil Sci., 63, 1-14.

Abd El-mageed, T.A., Belal, E.E. Rady, M.O.A., Abd El-mageed, S.A., Mansour, E., Awad, M.F., and Semida W.M. 2021. Acidified Biochar as a Soil Amendment to Drought Stressed (Vicia faba L.) Plants : Influences on Growth and Productivity, Nutrient Status, and Water Use Efficiency. Agronomy

Abid A. A., Mozammil H., Hafiz Saqib K.T., Touseef A. A., and Muhammad A. 2016. Foliar spray surpasses soil application of potassium for maize production under rainfed conditions. Turk J Field Crops 21(1):36-43.

Agami, R.A., Alamri, S.A.M., Abd ElMageed, T.A., Hashem, M.S.M., and Mohamed, A. 2018. Role of exogenous nitrogen supply in alleviating the deficit irrigation stress in wheat plants,. Agric. Water Manag., 210, 261-270

Allen, R.G., L.S., Pereira, D., Raes and Smith M. 1998. FAO Irrigation and Drainage Paper Crop by. Irrig. Drain. 300,300 .
Al-Mefleh, N.K., Samarah, N., Zaitoun, S., and Al-Ghzawi A. 2012. Effect of irrigation levels on fruit characteristics, total fruit yield and water use efficiency of melon under drip irrigation system. $\mathrm{J}$ Food Agric and Envir. 2: 540-545.

Badal, E., Abd El-Mageed, T. A., Buesa, A., Guerra, D., Bonet, L., and Intrigliolo D.S. 2013. Moderate plant water stress reduces fruit drop of "Rojo Brillante" persimmon (Diospyros kaki) in a Mediterranean climate. Agric Water Manage. 119: 154- 160.

Ben Ahmed, C., Ben Rouinab, B., Sensoyc, S., Boukhrisa, M., Ben Abdallah, F. 2009. Changes in gas exchange, proline accumulation and antioxidative enzyme activities in three olive cultivars under contrasting water availability regimes. Envir Exp Bot. 67: 345-352.

Beukema, H. P., and Van der Zaag, D. E. 1990. Introduction to potato production. Wageningen, The Netherlands, 224 pp.

Burbano, C. Cuadrado, C. Muzquiz, M., and Cubero, J.I. 1995. Variation of favism-inducing factors (vicine, convicine and L-DOPA) during pod development inVicia faba L. Plant foods Hum. Nutr., 47, 265-274.

Cakmak I. 2005. The role of potassium in alleviating detrimental effects of abiotic stresses in plants. J of Plant Nut and Soil Sci. 168: 521- 530

Cazzato, E., Tufarelli, V., Ceci, E., Stellacci, A.M., and Laudadio, V. 2012. Quality, yield and nitrogen fixation of faba bean seeds as affected by sulphur fertilization. Acta Agric. Scand. Sect. B Soil Plant Sci. 62, 732-738.

Chen, J.S., Kang, S., Du, T., Qiu, R., Guo, P., and Chen, R. 2013. Quantitative response of greenhouse tomato yield and quality to water deficit at different 
growth stages. Agric Water Manage. 129: $152-162$.

Clark, A. J., Landolt, W., Bucher, J. B., and Strasser, R. J. 2000. Beech (Fagus sylvatica) response to ozone exposure assessed with a chlorophyll a fluorescence performance index. Envir Poll. 109: 501-507.

Damon, P.M., and Rengel, Z. 2007. Wheat genotypes differ in potassium efficiency under glasshouse and field conditions. Aust J Agric Res. 58: 816- 823.

Danial, H.F., Ewees. M.S, and Moussa, S.A. 2010. Significance of influence potassium on the tolerance to induce moisture stress and biological activity of some legume crops grown on a sandy soil Egypt. Egypt J Soil Sci. 43:180-204

Dejong, T. M. 1996. Photosynthesis and respiration. In: Micke, W.C. (Ed.), Almond Orchard Management, vol. 3364. Uni. California, U.S.A., Division of Agriculture and Natural Resource, pp. 103-106.

El Sayed S. A. M, Ahmad, M. E. 2003. Effect of water shortage and potassium efficiency of symbiotic nitrogen fixation in some legumes. Egy $\mathbf{J}$ of Soil Sci. 43:193-210.

Giuliani, M. M., Nardella, E., Gatta, G., Quintadamo M., and De Caro, A. 2011. Processing tomato cultivated under water deficit conditions: the effect of Azoxistrobin. Acta Hortic.542 914:287294.

Gomez, K. A., and Gomez, A. A. 1984. Statistical Procedures for Agricultural Research, $2^{\text {nd }}$ ed. John Wiley \& Sons, Singapore, pp. 680.

Gonzalez, J. A., Gallardo, M., Hilal, M., Rosa, M., Prado, F. E. 2009. Physiological responses of quinoa (Chenopodium quinoa Willd.) to drought and waterlogging stresses: dry matter partitioning. Bot Studies 50:3542.

Habibi G. 2012. Exogenous salicylic acid alleviates oxidative damage of barley plants under drought stress. Acta Bio Szeged. 56: 57-63.

Hayat, S., Ali, B., Hasan, S.A., and Ahmad, A. 2007. Brassinosteroid enhanced the level of antioxidants under cadmium stress in Brassica juncea. Envir Exp Bot. 60: 33-41.

Howel, T. A. 2001. Enhancing water use efficiency in irrigated agriculture. Agron J. 93: 281-289.

Ijoyah, M.O., and Fanen, F.T. 2012. Effects of different cropping pattern on performance of maize-faba bean mixture in Makurdi, Nigeria. J. Crop Sci.1: 3947.

Jackson, M. L. 1973. Soil Chemical Analysis. Prentice Hall of India Private Limited, New Delhi, Indian.

Jones, H.G. 2004. What is water use efficiency? In: Bacon, M.A. (Ed.), Water Use Efficiency in Plant Biology. Blackwell Publishing, Oxford, UK, pp. 27-41.

Kabir ME, Karim MA, Azad MAK. 2004. Effect of potassium on salinity tolerance of mungbean (Vigana radiata $\mathrm{L}$. Wilczek). J. Bio Sci.4: 103-110.

Klute, A., and Dirksen, C. 1986. Hydraulic conductivity and diffusivity: Laboratory methods. In Methods of Soil Analysis: Part 1-Physical and Mineralogical Methods; Soil Science Society of America, American Society of Agronomy: Madison, WI, USA. 9, 687734.

Liu, H., Duan, A., Li, A., Sun, J., Wang, Y., and Sun, C. 2013. Drip irrigation scheduling for tomato grown in solar greenhouse based on pan evaporation in north China plain. J. Integr Agric. 12:520-531. 
Matusso, J. M. M., Mugwe, J. N., and Mucheru-Muna, M. 2014. Effects of different maize (Zea mays L.) - Faba bean (Glycine $\max$ (L.) Merrill) Intercropping patterns on yields and its economics. Academia J Agric Res. 2: 159-166.

Maxwell, K., and Johnson, G. N. 2000. Chlorophyll fluorescence - a practical guide. J Exp. Bot. 51:659-668.

Mengel, K., and Kirkby, E. A. 2001. Principles of Plant Nutrition. $5^{\text {th }}$ ed., Kluwer Academic Publishers, Dordrecht.

Nachi, N., and Le Guen, J. 1996. Dry matter accumulation and seed yield in faba bean (Vicia faba L.) genotypes. Agronomie, 16, 47-59.

Nuruddin M.M., Madramootoo, C.A., and Dodds, G.T. 2003. Effects of water stress at different growth stages on greenhouse tomato yield and quality. Hortic Sci. 38: 1389-1393.

Ofosu-Anim, J., and Leitch, M. 2009. Relative efficiency of organic manures in spring barley (Hordeum vulgare L.) production. Aust J. Crop 3: 13-19.

Page, A.L., Miller, R.H., and Keeney, D.R. 1982. Methods of Soil Analysis Part 2. Chemical and Microbiological Properties; American Society of Agronomy, Inc.: Madison, WI, USA.

Pereira, L. S., Oweis, T., and Zairi, A. 2012. Irrigation management under water scarcity. Agric. Water Manage. 57: 175-206.

Pieters, A. J, and Souki S.E. 2005. Effects of drought during grain filling on PSII activity in rice. J. Plant Physiol. 62: 903-911.

Ponce, V.M., Pandey, R. P, and Ercan, S. 2000. Characterization of drought across the climate spectrum. J. Hydro Engin. ASCE 5 (2): 222-224.
Rady, M. M. 2011. Effect of 24epibrassinolide on growth, yield, antioxidant system and cadmium content of bean (Phaseolus vulgaris L.) plants under salinity and cadmium stress. Scientia Horticulturae 129, 232-237.

Rouphael, Y., and Colla, G. 2005. Growth, yield, fruit quality and nutrient uptake of hydroponically cultivated zucchini squash as affected by irrigation systems and growing seasons. Hortic Sci. 105: 177-195.

Sangakkara, U.R., Frehner, M., and Nosberger, J. 2000. Effect of soil moisture and potassium fertilizer on shoot water potential, photosynthesis and partitioning of carbon in mungbean and cowpea. J Agron crop sci. 185: 201207.

Sinclair, T.R., Ludlow, M. M. 1986. Influence of soil water supply on the plant water balance of four tropical grain legumes. Aust J Plant Physio. 13: 329341.

Wang, F., Kang, S. Z, Du, T. S, Li, F. S., and Qiu, R. J. 2011. Determination of comprehensive quality index for tomato and its response to different irrigation treatments. Agric Water Manage. 98: 1228-1238.

Wei, M. I. N., Guo, H. J., Zhang, W., Zhou, G.W., Jun, Y. E., and Hou, Z. A. 2016. Irrigation water salinity and $\mathrm{N}$ fertilization: Effects on ammonia oxidizer abundance, enzyme activity and cotton growth in a drip irrigated cotton field. J. Integr. Agric., 15, 1121-1131.

Zeidan, M.S. 2003. Effect of sowing dates and urea foliar application on growth and seed yield of determinate faba bean (Vicia faba L.) under Egyptian conditions. J. Agron., 24, 93-102. 


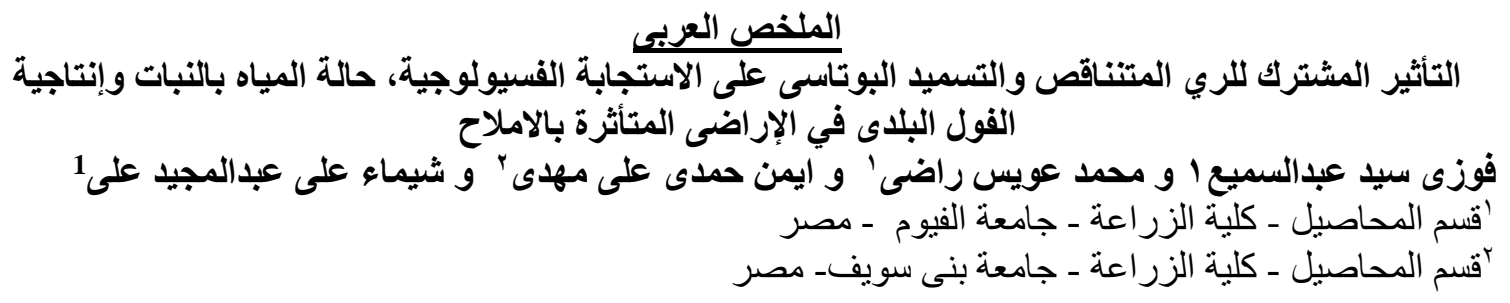

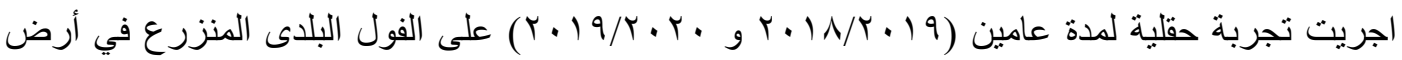

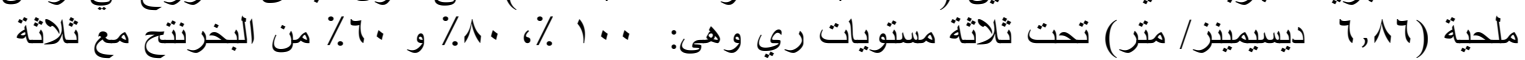

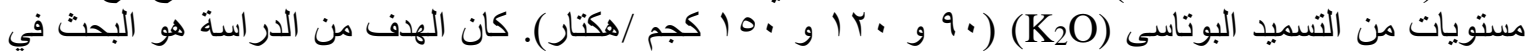

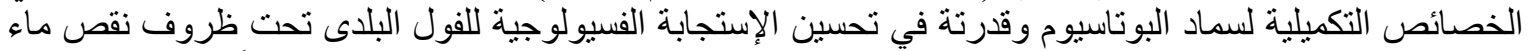

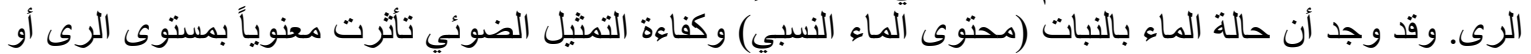

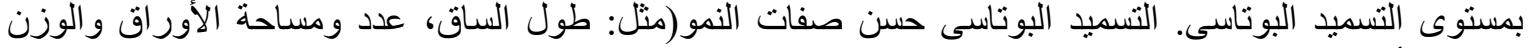

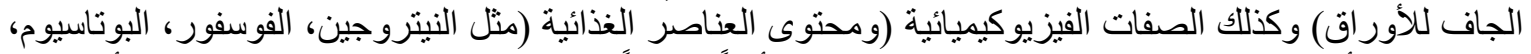

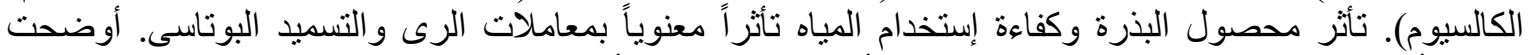

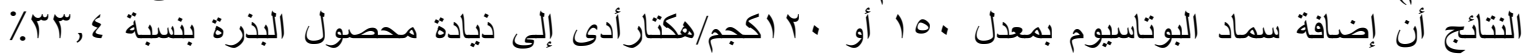

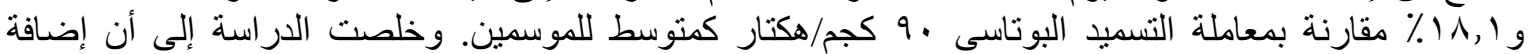

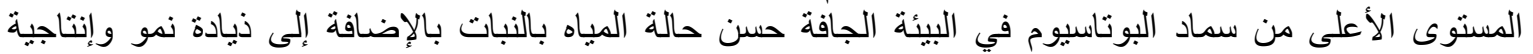
محصول الفول البلدى تحت الإجهاد المائى. فئ. 